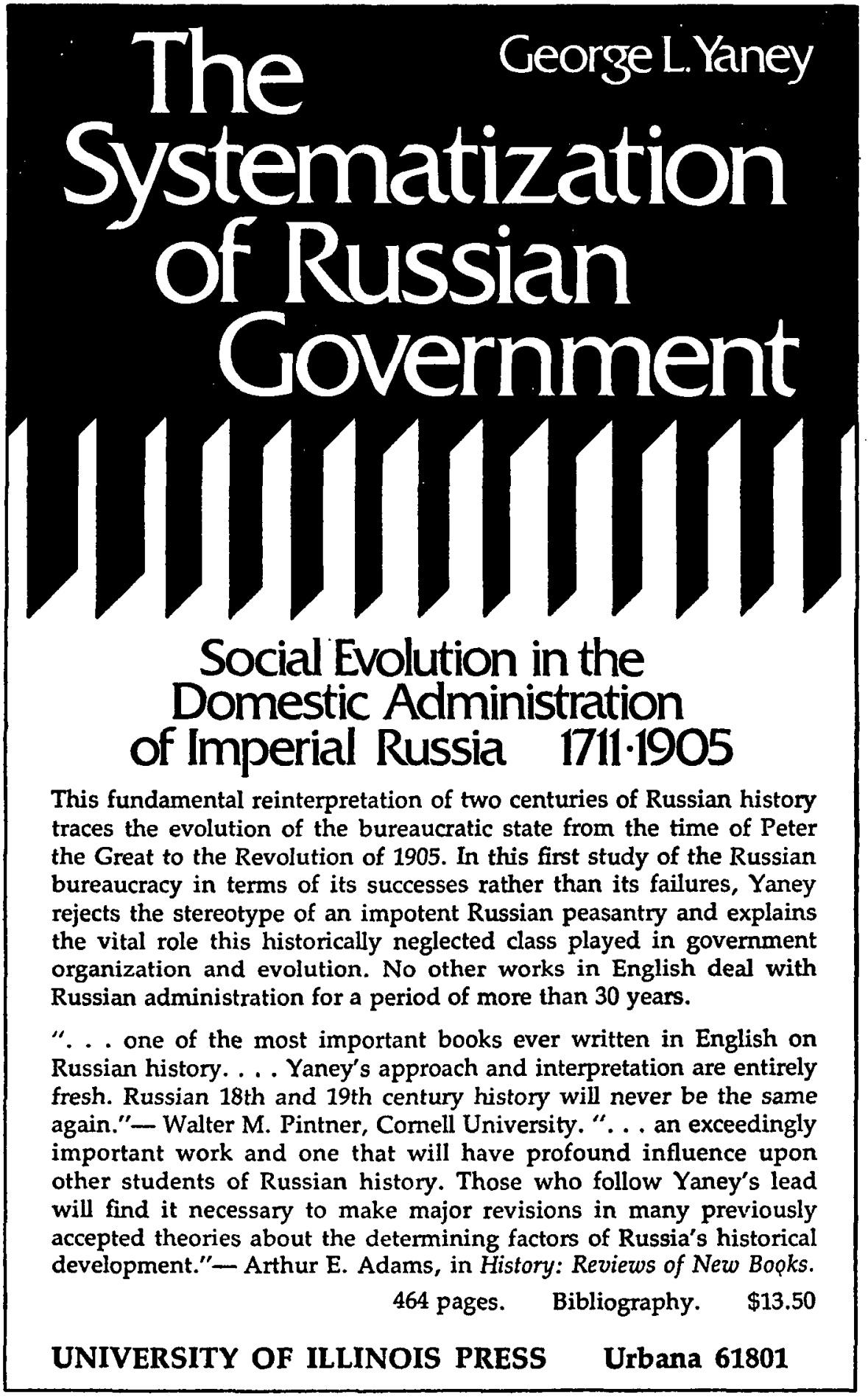




\section{IN FORTHCOMING ISSUES}

Michael F. Hamm, "Liberal Politics in Wartime Russia: An Analysis of the Progressive Bloc"

Donald E. Davis and Eugene P. Trani, "The American YMCA and the Russian Revolution"

Gregory L. Freeze, "Social Mobility and the Russian Parish Clergy in the Eighteenth Century"

Bernice Glatzer Rosenthal, "Nietzsche in Russia: The Case of Merezhkovsky"

Stephen White, "Communism and the East: The Baku Congress, $1920 "$

James R. Millar, "Mass Collectivization and the Contribution of Soviet Agriculture to the First Five-Year Plan"

Russell Zguta, "Origins of the Russian Puppet Theater: An Alternative Hypothesis"

Yeshayahu Jelinek, "Nationalism in Slovakia and the Communists, 1918-1929"

David W. Paul, "The Repluralization of Czechoslovak Politics in the 1960s"

Thomas H. Hoisington, "Melnikov-Pechersky: Romancer of Provincial and Old Believer Life"

Orest Subtelny, "Peter I's Testament: A Reassessment"

Lawrence D. Orton, "Did the Slavs Speak German at Their First Congress?"

Myron W. Hedlin, "Zinoviev's Revolutionary Tactics in 1917"

\section{TO THOSE WISHING TO SUBMIT MANUSCRIPTS:}

Unsolicited materials submitted by persons in the United States must be accompanied by return postage. The policy of the Slavic Review is not to consider materials that have been published or that are being considered for publication elsewhere. Footnotes should be double-spaced and placed at the end of the manuscript. Library of Congress transliteration should be used. 


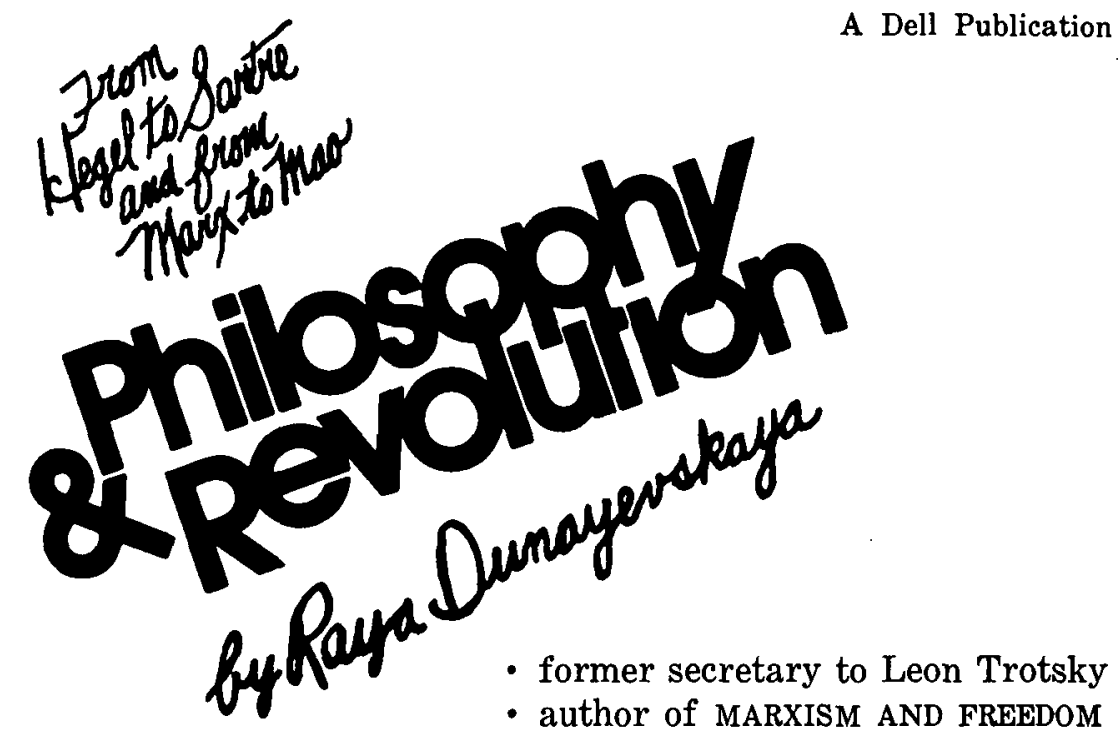

PART I-Why Hegel? Why Now? Hegel - Marx • Lenin's Philosophic Ambivalence

\section{PART II-Alternatives} Trotsky - Mao * Sartre

PART III-"The African

Revolutions and the World Economy" "State Capitalism and the East European Revolts" - "New Passions and New Forces"
". . . a very impressive and informative work, very thoughtful and original in conception as well as most remarkable in its scope ... (It) breaks new ground and should stimulate a good deal of debate and rethinking of many fundamental issues."

\section{-NOAM CHOMSKY}

"The spectre that has been haunting Mao since both the Hungarian Revolution and the 'Hundred Flowers' campaign manifested opposition from the Left, is that of Marx's Humanism. As the Sino-Soviet conflict first unfolded, Mao was fighting Khrushchev as a 'bourgeois humanist' and 'revisionist.' Within China, on the other hand, Mao made sure to develop the attack more comprehensively ...

"The Mao-Chou designation of Richard Milhous Nixon as 'less bad' than 'revisionist Russia' as an ally became the compelling need of a tripolar world ...

"The fact that presently everyone from Nixon-Kissinger to "populist Maoists' identify Mao and China as a single unbroken totalized unity cannot hide either the life-and-death divisions between the Chinese people and their rulers, or those within the 'Ieadership,' as Sheng Wu-lien's Manifesto, on the one hand, and the liquidation of Lin Piao on the other hand, prove."

-Philosophy and Revolution, Chapter 5, "The Thought of Mao Tse-tung"

Paperback: $\$ 2.95$

Hardcover: $\$ 8.95$
(Free special offer with each hardcover order: Raya Dunayevskaya's original (1941) study of Russia as State Capitalist Society.)

Order from: News \& Letters, 1900 E. Jefferson, Detroit, Mi. 48207 